\title{
Editorial
}

\section{Michael Gurstein and the future of community informatics}

\author{
Eduardo Villanueva- \\ Mansilla
}

\author{
Editor in Chief, The Journal of Community \\ Informatics \\ Corresponding Author. \\ evillan@gmail.com
}

Michael Gurstein, founder and main force behind this Journal and the Community Informatics movement, passed away October 8th, 2017. The multiple tributes and eulogies around the world and on the Internet bear witness of a life well lived and a career that touched many lives.

As his "written" home, the Journal will publish a collection of tributes in the coming months, in the form of an extraordinary issue of JoCI. His passing is also a moment to reflect on his intellectual journey and how it, to a point, reflects on the transformations of the Internet and the movement he promoted for well over two decades.

At the beginning, the community was the locus of his attention, and projects to promote access a source of critical appraisal. How to separate the good (access to information and community engagement and cohesion) from the simply commercial, to create new markets for telecommunications conglomerates through public financing? The digital divide debates of early 2000s have receded to the background, but the discussions have resurfaced in new forms and formats. How to promote access that doesn't mean just consumption on one universal service, fitted and shaped around the priorities of global capital? From Facebook to the Unicorn of the day, in the end the concerns are quite similar, even if the terrain has been changed beyond (apparent) recognition: should the ideals of a democratic society be subordinated to the intent and interests of global capital? should the citizen be put on a secondary plane, favoring the consumer? By this last decade, Michael's concerns had moved to the global debate on Internet governance. It was not a technical stance that interested him: again, his focus was the fight for a democratic, people-centered Internet against the corporate

Villanueva-Mansilla, E. (2017). Michael Gurstein and the future of community informatics (editorial). The Journal of Community Informatics, 13(3), 1-3.

Date submitted: 2017-12-30. Date accepted: 2017-12-31.

Copyright (C), 2017 (the authors as stated). Licensed under the Creative Commons AttributionNonCommercial-ShareAlike 2.5. Available at: ci-journal.net. Aquí debería ir el enlace completo. 
takeover by a few giants. While some years ago that may have meant finding a way to bring connectivity to communities, what's at stake now is how to use that connectivity, how to go beyond commercial services and to effective use.

This concept is critical: as the "The capacity and opportunity to successfully integrate ICTs into the accomplishment of self or collaboratively identified goals" (Gurstein, 2003), effective use best encapsulates the notion of going beyond access to achieve some level of embeddedness into community, societal or national policies and applications of ICT / Internet / digital media. The modal nature of ICT, and by extension of digital media, provides a variety of potential uses to all those interested; the power of established actors to influence policy and consumption decisions can only be faced through the use of all the tools brought to bear by ICTs as resources for self-expression and self-determination.

As the debate evolved, so the concerns of Michael moved towards the larger issues: the digital divide stopped being relevant as a category or term for policy debates, though it was still being used as a banner by the different iterations of corporate position papers; the notion of multistakeholderism was debated as a cover for industrial influence on political discussions at all levels, and as a way for governments to abdicate their responsibilities to their citizens.

In every one of these debates, Michael provided clear and precise inputs. The discussions about Internet governance, as a debate about democracy or multistakeholderism; the notion of a "digital citizenship" as correlated to a "global Internet community"; the characterization of the Internet as a global public good; social justice and the Internet and its governance; and of course, that old chestnut, the "information society", and its relationship with the actual developments that ICT / Telecommunications / digital media were bringing forward. In all these issues, Michael debated from a clear position: whatever the construct, concept or position, do not forget that the only guarantee of democracy and fairness is to take communities into account.

This principle is still relevant, both as an academic, intellectual starting point to study the societal impact of ICTs, as well as a counterpoint to the insistent approaches towards "democratization" of access that corporate actors are conducting globally in many forms. It is the basis of a critical understanding of the political dimensions of ICTs, in a clear and simple formulation, that we in academia sometimes neglect to posit when trying to explain the digital phenomena enveloping and shaping our current world. And there is where the strength and relevance of community informatics lies, and should remain, in the coming years.

Our colleagues, sharing their work in this Journal, are a good example of the intersection between a critical approach and an academic elaboration of the issues involved in the digital world. Citizen Science, Open Development, Women, Health work: the subjects covered by the papers published in this issue, are pertinent responses to the overwhelming emphasis that digital media consumption appears to promote all around the world; that is to say, that the "digital revolution" is basically reduced to one aspect, consumption and personal satisfaction. Instead, the potential to provide and promote the promise of a brave new alternative for a better world, where more and more people are able to find a way to take control and use ICT 
access to enhance their daily lives, is still the main thrust of the CI community and of the work showcased in this Journal.

While we all miss Michael, his work is a beacon, leading to a simple, powerful but somehow far away idea: that people and by extension, communities, should be at the center of development, and specifically, of digital developments. I sincerely hope that this Journal is helping to drive this point home; and I expect that it continues to do so as long as it is relevant and viable. As a fully open journal, it has as many challenges as it had when it began; it is the community itself, those involved in community informatics in all its shades and hues, that keep it viable. As a custodian of an idea and of a precise incarnation of such an idea, I thank Michael for the chance to keep this project alive, and look forward for many years of continuing work allowing for a powerful community to expand and change along with the times.

\section{References}

Gurstein, M. (2003). Effective use: A community informatics strategy beyond the Digital Divide. First Monday, 8(12), Dec. 2003. Retrieved from http://firstmonday.org/article/ view/1107/1027 